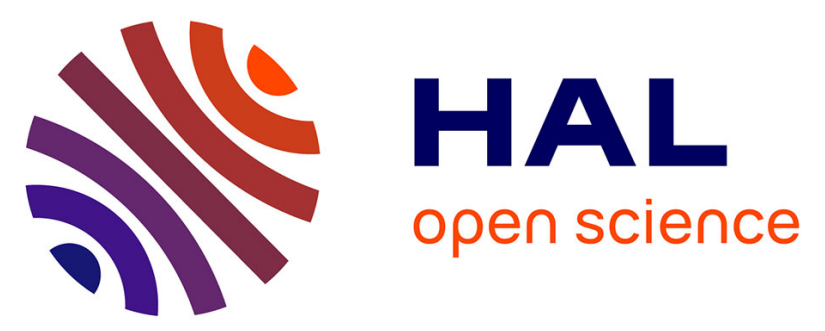

\title{
Electrochemical properties of silver-copper alloy microelectrodes for use in voltammetric field apparatus
}

Silje M. Skogvold, Mikkelsen Øyvind, Billon Gabriel, Cédric Garnier, Lesven

Ludovic, Jean-Francois Barthe

\section{- To cite this version:}

Silje M. Skogvold, Mikkelsen Øyvind, Billon Gabriel, Cédric Garnier, Lesven Ludovic, et al.. Electrochemical properties of silver-copper alloy microelectrodes for use in voltammetric field apparatus. Analytical and Bioanalytical Chemistry, 2006, 384, pp.1567 - 1577. 10.1007/s00216-006-0334-4 . hal-01096812

\section{HAL Id: hal-01096812 \\ https://hal-univ-tln.archives-ouvertes.fr/hal-01096812}

Submitted on 5 Jan 2015

HAL is a multi-disciplinary open access archive for the deposit and dissemination of scientific research documents, whether they are published or not. The documents may come from teaching and research institutions in France or abroad, or from public or private research centers.
L'archive ouverte pluridisciplinaire HAL, est destinée au dépôt et à la diffusion de documents scientifiques de niveau recherche, publiés ou non, émanant des établissements d'enseignement et de recherche français ou étrangers, des laboratoires publics ou privés. 


\section{Silje M. Skogvold • Øyvind Mikkelsen • Gabriel Billon • Cedric Garnier • Ludovic Lesven • Jean-Francois Barthe \\ Electrochemical properties of silver-copper alloy microelectrodes for use in voltammetric field apparatus}

Received: 30 September 2005 / Revised: 25 December 2005 / Accepted: 27 January 2006 / Published online: 21 March 2006 (C) Springer-Verlag 2006

\begin{abstract}
Microelectrodes of silver-copper alloys have been evaluated for use in voltammetric analyses. Increased overpotential towards the hydrogen overvoltage reaction (HER) was found as a function of increased copper content in the silver. A study of oxidizing products by cyclic voltammetry $(\mathrm{CV})$ in $\mathrm{NaOH}$ solution showed ten anodic and eight cathodic peaks which are described in the present paper. The behaviour of these alloy electrodes is somewhere between pure silver and pure copper electrodes. Differential pulse anodic stripping voltammetry (DPASV) was used to measure zinc, cadmium and lead in ultrapure water only $(18 \mathrm{M} \Omega \mathrm{cm})$, and good linearity was found for all metals $\left(r^{2}=0.998\right)$ in the range of 0.5 to $5 \mathrm{ppb}$ with a 600 - to 1,200 -s plating time. It was additionally found that cadmium and lead were better separated on the alloy electrodes compared to pure silver electrodes. Measurements of nickel were carried out on alloy electrodes by use of adsorptive differential pulse cathodic stripping voltammetry (Ad-DPCSV), and good linearity $\left(r^{2}=1.000\right)$ was found in the range from 0.5 to $5 \mathrm{ppb}$ with an adsorption time of $120 \mathrm{~s}$. The alloy electrodes were also found to be sensitive to nitrate, and good linearity $\left(r^{2}=0.997\right)$ was found in the range from $1 \mathrm{mg} \mathrm{L}^{-1}$ to $100 \mathrm{mg} \mathrm{L}^{-1}$ using differential pulse voltammetry (DPV) scanning from $-450 \mathrm{mV}$ to $-1,500 \mathrm{mV}$. Addition of nitrate in ultrapure water afforded two different peaks related to the successive reductions of nitrate and nitrite. In ammonium buffer
\end{abstract}

\footnotetext{
S. M. Skogvold $\cdot \varnothing$. Mikkelsen $(\bowtie)$

Norwegian University of Science

and Technology Department of Chemistry,

7491 Trondheim, Norway

e-mail: oyvind.mikkelsen@chem.ntnu.no

e-mail: silje.skogvold@chem.ntnu.no

G. Billon · C. Garnier · L. Lesven · J.-F. Barthe

University of Sciences and Technologies of Lille,

Laboratory of Analytical and Marine Chemistry (UMR8013),

59655 Villeneuve d'Ascq, France

e-mail: gabriel.billon@univ-lille1.fr

e-mail: cgarnier@univ-tln.fr

e-mail: ludoviclesven@univ-lille1.fr

e-mail: jean-francois.barthe@univ-lille1.fr
}

solution $(\mathrm{pH}$ 8.6) only one peak resulting from reduction of nitrate was observed. Furthermore, the use of alloy electrodes containing $17 \% \mathrm{Cu}$ was tested in real samples, by installing it in a voltammetric system for monitoring of zinc and lead in a polluted river, the river Deûle, near the town of Douai in northern France. Results were found to be in agreement with parallel measurements carried out by ICP-MS.

Keywords Voltammetry $\cdot$ Solid electrodes $\cdot$ Real samples

\section{Introduction}

Increasing focus on environmental surveillance $[1,2]$ has created a demand for continuous improvements and development of usable field instruments and sensors. Heavy metals represent an important group of contaminants, and monitoring of these species in the field is of great importance to avoid serious environmental damage. Pollution by heavy metals, even in small concentrations, may have deadly influences on the surroundings [3-5].

The most frequently used methods in environmental monitoring today are atomic absorption spectroscopy (AAS) and inductively coupled plasma-mass spectroscopy (ICP-MS). However, in order to carry out continuous online monitoring, these methods are too complicated. Electrochemical techniques represent an alternative, fastmeasuring and inexpensive group of methods useful for monitoring heavy metals. Different types of voltammetric methods are particularly suitable [6-17], and voltammetric apparatus for online monitoring of metal speciation can be constructed [18].

In order to succeed in making voltammetric field apparatus for online monitoring of heavy metals, a critical factor is to develop usable electrodes. Liquid mercury represents the most frequently used material for electrodes in voltammetry; however, in field apparatus a liquid mercury electrode is difficult to install, and solid electrodes represent an easier alternative. Intensive research has been carried out in recent years in order to develop useful solid 
electrodes [18-27]. However, the main problems with solid electrodes are lack of overpotential towards the hydrogen evolution reaction in water solutions, and problems with the stability over time due to adsorptions of organic or charged compounds on the electrode surface or formation of insulating oxide layers.

A proper combination of chemical and electrochemical cleaning may overcome the problem of passivation to some extent, and increase the time between manual maintenance of the electrodes long enough to make it of potential use in the field $[28,29]$. However, the problem with low overvoltage towards the hydrogen evolution reaction still has to be dealt with, since most solid metal electrodes actually have a relatively low overvoltage towards hydrogen evolution. This makes them unsuitable for analyses of several important metals like nickel, cobalt, zinc, iron and cadmium. Studies of specific mixed metal electrodes, containing two or more metals, have shown a significant increase in overvoltage towards hydrogen evolution and are promising for use in field apparatus. Of specific interest are electrodes containing silver doped with one or more metals (e.g. mercury, bismuth or copper) which have a high overvoltage towards the hydrogen evolution reaction [30-32].

Nitrate is another important compound to measure in environmental monitoring, because of its important influence on the environment. Several papers have been published on the subject of fundamental processes associated with the reduction of nitrate with various metal substrates [48-56]. However, only a few papers focus on the analytical aspect, and the possibility of using voltammetric techniques with solid electrodes for determination of nitrate in the environment [57-63]. Development of sensitive methods for measuring nitrate in the field is therefore of great interest and importance.

Performing voltammetric analyses in the field also requires a proper system for adding supporting electrolyte and stirring the solution. Even though it is possible to construct such a system, it should as easy as possible to build. Measurements with microelectrodes makes it possible to avoid use of supporting electrolyte and in some cases also the agitation of the solution during the plating time in differential pulse stripping voltammetry [33]. Furthermore, the sensitivity is improved owing to an improved ratio of faradic to charging current and signal to noise ratio. Because of this, the use of such small electrodes has great advantages for use in field apparatus. Several papers dealing with microelectrodes have been published [34-38], and silver and gold microelectrodes are of special interest. In this contribution 80- $\mu \mathrm{m}$ electrodes of have been used. These electrodes represent the upper limit regarding the definition of microelectrodes; however, microelectrode behaviour was observed.

In view of the problems discussed above concerning overpotential towards the hydrogen evolution reaction, passivation and formation of oxide layers, and stability over time, voltammetric electrodes should be made in a way as to overcome these problems as best as possible. This paper deals with a study of mixed microelectrodes of silver and copper. Such alloys are noted for their good stability, serving as materials in jewellery for hundred of years. Furthermore, when alloying these metals, structural changes in the surface could improve the overvoltage towards the hydrogen evolution reaction, something which is studied in this paper. Some practical applications of these microelectrodes in real samples of polluted river water are also demonstrated.

\section{Experimental}

Analyses were performed with voltammetric equipment from PalmSens (The Netherlands) together with a threeelectrode system using a platinum counter electrode, an $\mathrm{Ag} / \mathrm{AgCl} / \mathrm{KCl}(3 \mathrm{M})$ reference electrode, and silver-copper alloys were used as working quasi-microelectrodes $(d=$ $80 \mu \mathrm{m})$. Additionally, as specified in the text below, some analyses were performed with a homemade potentiostat. Oxygen was not removed from any of the samples.

The silver alloys were ordered as wires from K. A. Rasmussen, Hamar, Norway. The alloys tested were silver 830 (83\% silver and 17\% copper) and silver 925 (92.5\% silver and $7.5 \%$ copper). Additionally, pure silver wire (99.99\%), ordered from Goodfellow Company (UK), was used for making silver microelectrodes for comparative measurements. The electrodes were made in a similar way to gold and silver microelectrodes described elsewhere [39], by gluing together $4-5 \mathrm{~cm}$ of the silver or silver alloy wires to a copper wire connector and then sealing the respective wires in polyethylene pipette tips $(200 \mu \mathrm{L})$ at $500{ }^{\circ} \mathrm{C}$. A second tip enclosing the whole device was finally stuck to the first one and fixed with non-conductive epoxy glue.

The electrodes were first polished on P2,500 and secondly on P4,000 (Struers) grid papers, before polishing with diamond paste $(1 \mu \mathrm{m}$, Struers). After polishing, the electrodes were checked with an optical microscope (Reichert, Austria) at magnification from $110 \times$ to $320 \times$. The electrodes were rinsed under ultrasound for $60 \mathrm{~s}$, first in ultrapure ethanol and then in ultrapure $\mathrm{HNO}_{3}(10 \%)$ solution before they were rinsed in ultrapure water $(18 \mathrm{M} \Omega \mathrm{cm})$. Finally, the electrodes were checked by cyclic voltammetry, scanning 9 cycles in ultrapure water (18 $\mathrm{M} \Omega \mathrm{cm}$ ) between $-1,350 \mathrm{mV}$ and $-50 \mathrm{mV}$, starting from $-350 \mathrm{mV}$ at a scanning rate of $100 \mathrm{mV} \mathrm{s}^{-1}$.

Standard solutions of zinc, lead and cadmium $\left(100 \mu \mathrm{g} \mathrm{L}^{-1}, 500 \mu \mathrm{g} \mathrm{L}^{-1}\right.$ and $\left.1 \mathrm{mg} \mathrm{L}^{-1}, 10 \mathrm{mg} \mathrm{L}^{-1}\right)$ were prepared by dilution of $1,000 \mathrm{mg} \mathrm{L}^{-1}$ metal solutions (CertiPur, Merck) in deionised water, which was subsequently purified with a Milli-Q Plus apparatus (Millipore, resistivity $18 \mathrm{M} \Omega \mathrm{cm})$. All other reagents $\left(\mathrm{HNO}_{3}\right.$ and $\mathrm{HCl}$ (suprapur, Merck), $\mathrm{NaOH}, \mathrm{NH}_{4} \mathrm{Cl}, \mathrm{NH}_{3}$, dimethylglyoxime, $\left.\mathrm{KNO}_{3}, \mathrm{C}_{2} \mathrm{H}_{5} \mathrm{OH}\right)$ were of analytical grade.

Studies of overvoltage towards the hydrogen evolution reaction were performed by linear scan voltammetry in $\mathrm{HCl}$ $(0.1 \mathrm{M})$ and $\mathrm{HNO}_{3}(0.01 \mathrm{M})$ solutions with a scan rate of $15 \mathrm{mV} \mathrm{s}^{-1}$. Oxide products were studied by cyclic voltammetry in $\mathrm{NaOH}(1 \mathrm{M})$ solutions. The electrodes 
were scanned 9 times between $-1,300$ and $800 \mathrm{mV}$ at a scan rate of $100 \mathrm{mV} \mathrm{s}^{-1}$, starting at $-50 \mathrm{mV}$.

Laboratory measurements of zinc, cadmium and lead in ultrapure water $(18 \mathrm{M} \Omega \mathrm{cm})$ using the alloy electrodes were performed in a $30-\mathrm{mL}$ cell system by differential pulse anodic stripping voltammetry. Plating time was $600 \mathrm{~s}$ and $1,200 \mathrm{~s}$ at $-1,250 \mathrm{mV}$, the scan rate was $15 \mathrm{mV} \mathrm{s}^{-1}$ and modulation pulse was $70 \mathrm{mV}$. Similarly, nickel was determined by use of adsorptive differential pulse cathodic stripping voltammetry (Ad-DPCSV) with a working electrode consisting of silver containing 17\% copper (silver 830). Standard additions of nickel were carried out in ammonium chloride solution adjusted to $\mathrm{pH} 8.6$ with $\mathrm{NH}_{3}$, and dimethylglyoxime $(210 \mu \mathrm{M})$.

Measurements of nitrate were performed with a silver electrode containing $17 \%$ copper, both in ultrapure water and in ammonium buffer solution ( $\mathrm{pH} 8.6)$, using differential pulse voltammetry by scanning from $-450 \mathrm{mV}$ to $-1,500 \mathrm{mV}$ at a scan rate of $15 \mathrm{mV} \mathrm{s}^{-1}$. Nitrate was added as $\mathrm{KNO}_{3}$. Prior to each scan, the electrode was kept at $-450 \mathrm{mV}$ for $20 \mathrm{~s}$ to stabilize the initial current and improve the baseline.

Measurements of zinc and lead in real samples were carried out in the river Deûle, a polluted river near the town of Douai, France. The sampling point was about 500-m upstream from a former metallurgical industry site (Metaleurop industry). Measurements were carried out for a period of $3 \mathrm{~h}$ using the portable PalmSens potentiostat. Each sample was quantified by using individual standard additions (two-point addition). Manual samples (filtered and unfiltered) were collected and acidified to $\mathrm{pH} 2$ with $\mathrm{HNO}_{3}$, for comparative measurement by ICP-MS (X Series, Thermo Elemental). Manual samples (unfiltered) were also used to test repeatability by DPASV. Samples were automatically brought to the cell system using a plastic $\mathrm{CO} / \mathrm{TECH}$ pump immersed in the river water. The pump was mounted on a floating stage by fixing the pump at a level of $0.5 \mathrm{~m}$ below the water surface. The pump supplied two at-line homemade Teflon cells $(65-\mathrm{mL}$ internal volume) with water samples. The first cell was used to perform $\mathrm{pH}$ measurements, using a $\mathrm{pH}$-combined microelectrode (Radiometer) linked to a $\mathrm{pH}$ meter (Meterlab PHM210, Radiometer). The second cell was used for voltammetric analyses of zinc and lead using the PalmSens voltammetric equipment. The working electrode was a silver-copper electrode (silver 830). Both cells were equipped with magnetic stirrers (Radiometer), and were continuously stirred between the voltammetric measurements to prevent sedimentation of particles. The sampling and measurement sequence was initiated by rinsing both cells for 5 min with a continuous flow of river water through the system, while simultaneously cycling the voltammetric working electrode three times between $-1,500$ and $-50 \mathrm{mV}$ at a scan rate of $100 \mathrm{mV} \mathrm{s}^{-1}$. The sampling pump was then stopped, and the magnetic stirrer installed in the voltammetric system was switched on during a plating time of up to $300 \mathrm{~s}$. After a resting time of an additional $15 \mathrm{~s}$, a DPASV scan was carried out.

\section{Results}

Overvoltage towards the hydrogen evolution reaction (HER)

An important aspect in finding useful electrodes for analytical purposes in voltammetry is to develop electrodes from materials with specific electrochemical properties, and of particular importance are properties concerning overvoltage towards the hydrogen evolution reaction (HER).

As seen in Fig. 1, a moderate increase in overvoltage towards HER both in $\mathrm{HNO}_{3}$ and $\mathrm{HCl}$ solutions was found for the silver-copper alloy electrodes. The increase in overvoltage towards hydrogen in acid solutions is somewhat surprising, since silver and copper have similar properties concerning the overvoltage towards the hydrogen evolution reaction [40]. However, when an alloy is formed, its physical and chemical properties including the overvoltage towards hydrogen evolution may be significantly different from the pure metals. Changes in the surface chemistry can be explained from changes in the electronic structure of the surface, resulting in modifications of the adsorption energetics and altering the barrier for reactions.

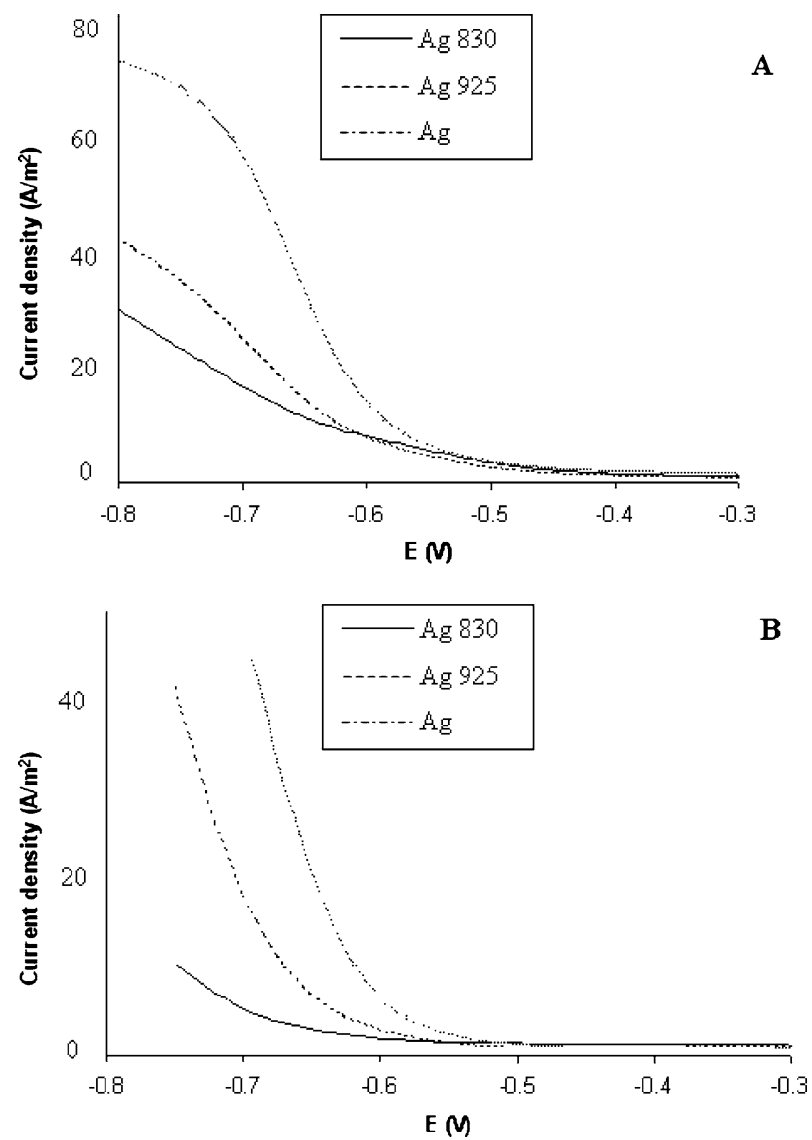

Fig. 1 Linear scan of pure silver, silver 830 and silver 925 in a $\mathrm{HNO}_{3}(0.01 \mathrm{M})$ and $\mathbf{b} \mathrm{HCl}(0.1 \mathrm{M})$. Scan rate was $15 \mathrm{mV} \mathrm{s}^{-1}$, and the scan was performed after a 5 -s resting time 
This effect may be local to an alloying atom, or it may be longer range. Furthermore, the introduction of different species into a surface creates chemically different sites on the surface. This provides a range of different sites for e.g. adsorption, and hence will also change the distribution of transition states available for reaction or dissociation [41]. The increasing overvoltage towards hydrogen could therefore be explained from a decrease in the total coverage of adsorbed hydrogen on the electrode surface, or due to changes in the activation energies for the hydrogen evolution reaction.

Stability and formation of oxides on the electrode surface

Investigations of the electrochemical behaviour of silver in $\mathrm{NaOH}$ have previously been carried out by Abd El Rehim et al. [42]. They found that the anodic polarization curve of silver in $\mathrm{NaOH}$ is characterized by five anodic peaks, and that the cathodic curve shows four peaks, one anodic and three cathodic. Studies of oxide layer formation on silvercopper alloys in $\mathrm{NaClO}_{4}$ solutions and in $\mathrm{NaOH}$ solutions have shown additional peaks originating from copper and copper oxides in the alloyed electrodes [43, 44].

This paper includes a study of silver-copper alloys containing down to $7.5 \%$ added copper, and therefore an alloy consisting of only a eutectic $\alpha$-phase. In the papers referred to above higher amounts of copper were used and those alloys therefore consisted of mixtures of both eutectic $\alpha$-phase and eutectic $\beta$-phases. It is therefore of interest to study if this difference significantly changes the electrochemical properties and the formation of oxide layers. A brief study of possible oxidizing products forming on the silver copper alloy electrodes was therefore carried out in $\mathrm{NaOH}(1 \mathrm{M})$ solution with cyclic voltammetry for electrodes of polycrystalline silver, silver containing $7.5 \%$ added copper and silver containing $17 \%$ added copper. Each electrode was cycled 9 times between $-1,300 \mathrm{mV}$ and $800 \mathrm{mV}$, starting from $-50 \mathrm{mV}$.

The cyclic voltammograms, shown in Fig. 2, are in good agreement with findings in the work referred to above $[42,43]$. In the resulting voltammograms ten anodic peaks (eight in the anodic direction and two in the cathodic direction), and eight cathodic peaks in the cathodic direction were observed. In the anodic direction A1 to A8 presumably correspond to formation of $\mathrm{Cu}_{2} \mathrm{O}$ (A1), formation of $\mathrm{Cu}(\mathrm{OH})_{2}$ (A2), formation of $\mathrm{CuO}(\mathrm{A} 3)$, dissolution of silver as soluble $\left[\mathrm{Ag}(\mathrm{OH})_{2}\right]^{-}$complex (A4), formation of $\mathrm{Ag}_{2} \mathrm{O}$ monolayer (A5), further nucleation and growth of multilayer of $\mathrm{Ag}_{2} \mathrm{O}$ (A6), electrooxidation of $\mathrm{Ag}_{2} \mathrm{O}$ and $\mathrm{Ag}$ to $\mathrm{AgO}$ (A7), and formation of $\mathrm{Ag}_{2} \mathrm{O}_{3}$ (A8). The two anodic peaks observed in the cathodic
Fig. 2 Cyclic voltammetry of $\mathbf{a}$ the first scan and $\mathbf{b}$ the ninth scan (magnified on the right) of silver, silver containing $7.5 \%$ added copper and silver containing $17 \%$ added copper electrodes in $\mathrm{NaOH}(1 \mathrm{M})$. Scan going from $-50 \mathrm{mV}$ to $900 \mathrm{mV}$ to $-1,300 \mathrm{mV}$, scan rate was $100 \mathrm{mV} \mathrm{s}^{-1}$. Peaks are marked with asterisks. The cathodic peaks in the cathodic scan are assumed to correspond to electroreduction of $\mathrm{Ag}_{2} \mathrm{O}_{3}$ and $\mathrm{AgO}$ to $\mathrm{Ag}_{2} \mathrm{O}(\mathrm{Cl})$, electroreduction of different $\mathrm{Ag}(\mathrm{I})$ species, $\mathrm{Ag}_{2} \mathrm{O}$ to $\mathrm{Ag}(\mathrm{C4}$ and $\mathrm{C5}), \mathrm{AgO}^{-}$to $\mathrm{Ag}(\mathrm{C} 6)$, reduction of $\mathrm{CuO}$ to $\mathrm{Cu}_{2} \mathrm{O}(C 7)$, and reduction of $\mathrm{CuO}_{2}$ and $\mathrm{Cu}(\mathrm{OH})_{2}$ to $\mathrm{Cu}(C 8)$. Chloride ions possibly leaking from the reference electrode could also attribute to the $\mathrm{C} 5$ peak
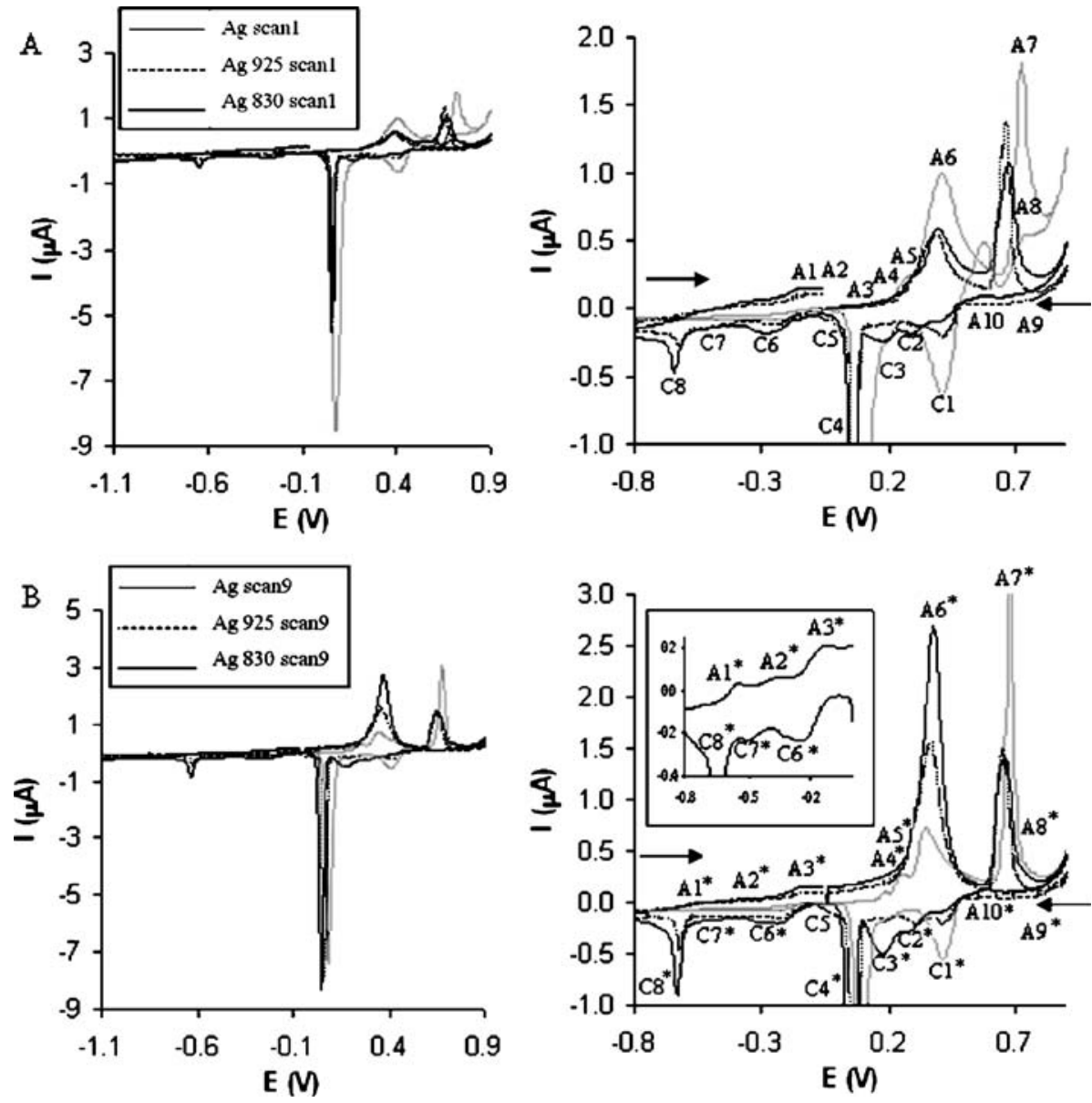
directions are assumed to correspond to further nucleation and growth of $\mathrm{Ag}_{2} \mathrm{O}_{3}$ (A9) and $\mathrm{Ag}_{2} \mathrm{O}$ (A10).

Due to the solubility data for copper in silver [45], the two electrodes studied in this work will have some difference in composition. In the silver electrodes containing $7.5 \%$ added copper only a eutectic $\alpha$-phase (solid solution of copper in silver) is present. In the silver electrodes containing $17 \%$ added copper the structure will be a mixture of a eutectic $\alpha$-phase and eutectic $\beta$-phase (solid solution of silver in copper).

Several changes were observed in the cyclic voltammograms, both as a function of number of scans and as a function of copper in the silver electrodes. In addition to the peaks A1, A2, A3, C6, C7 and $\mathrm{C} 8$, which are directly related to copper, a significant increase in peak $\mathrm{A} 6$ and decrease in peak A7 is also observed with increasing copper content in the silver electrode. Furthermore, the peaks A4, A5, C1, C4 and C5 are significantly decreased with an increase of copper in the electrode, and A4, A5, A8 and $\mathrm{Cl}$ are more or less not observed at all, while a significant peak $\mathrm{C} 3$ appears in the ninth voltammetric scan for the electrode containing $17 \%$ added copper as seen in Fig. 2.

The significant changes in peak A5 (corresponding to formation of $\mathrm{Ag}_{2} \mathrm{O}$ monolayer) with increasing copper in the electrode could be a result of copper dissolution overlapping with the A5 peak. This assumption is supported by the fact that the height of peak A5 increased significantly with number of cyclic scans for the electrodes containing added copper compared to pure silver electrodes, and could also explain the $\mathrm{C} 3$ peak which could be attributed to bulk deposition of copper. This observation could be explained by a possible increase in the amount of free copper ions building up near the electrode surface. An interesting point is that since copper is oxidized before silver and reoxidized after silver, the ratio of copper and silver ions near the electrode surface could change with increasing number of scans. This means that with an increasing number of scans the electrode surface could be coated by increasing amounts of copper. This assumption is supported by the fact that many of the anodic and cathodic peaks observed for pure silver are significantly decreased or not observed at all in the ninth cyclic scan of the electrodes containing added copper as seen in Fig. 2.

It is also evident that the anodic peaks A9 and A10, which occur in the cathodic direction, are absent in all voltammetric scans for the electrodes containing added copper, which could indicate that the formation of $\mathrm{Ag}_{2} \mathrm{O}_{3}$ and further nucleation and growth of $\mathrm{Ag}_{2} \mathrm{O}_{3}$ (A9) and $\mathrm{Ag}_{2} \mathrm{O}$ (A10) are suppressed when copper is present in the electrode. This is in agreement with the a report from Zaky et al. [44] in which they found that the dissolution rate of silver from alloys with copper is slower than from pure silver.

On the basis of the papers referred to above, and from the results obtain in this paper we conclude that addition of copper to the silver results in a slower release of silver ions,
Fig. 3 DPASV of standard additions of zinc a $3,5,7$ and $10 \mu \mathrm{g} \mathrm{L}^{-1}, \mathbf{b} 0.5,1$, and $2.5 \mu \mathrm{g} \mathrm{L}^{-1}$ in ultrapure water (18 $\mathrm{M} \Omega \mathrm{cm})$. Used electrode was silver containing $17 \%$ added copper, scan rate was $15 \mathrm{mV} \mathrm{s}^{-1}$, modulation pulse $70 \mathrm{mV}$ and deposition times were $600 \mathrm{~s} \mathrm{(a)} \mathrm{and} 1,200 \mathrm{~s}(\mathbf{b})$ at $-1,250 \mathrm{mV}$. Relative standard deviation was $3.2 \%(n=5)$
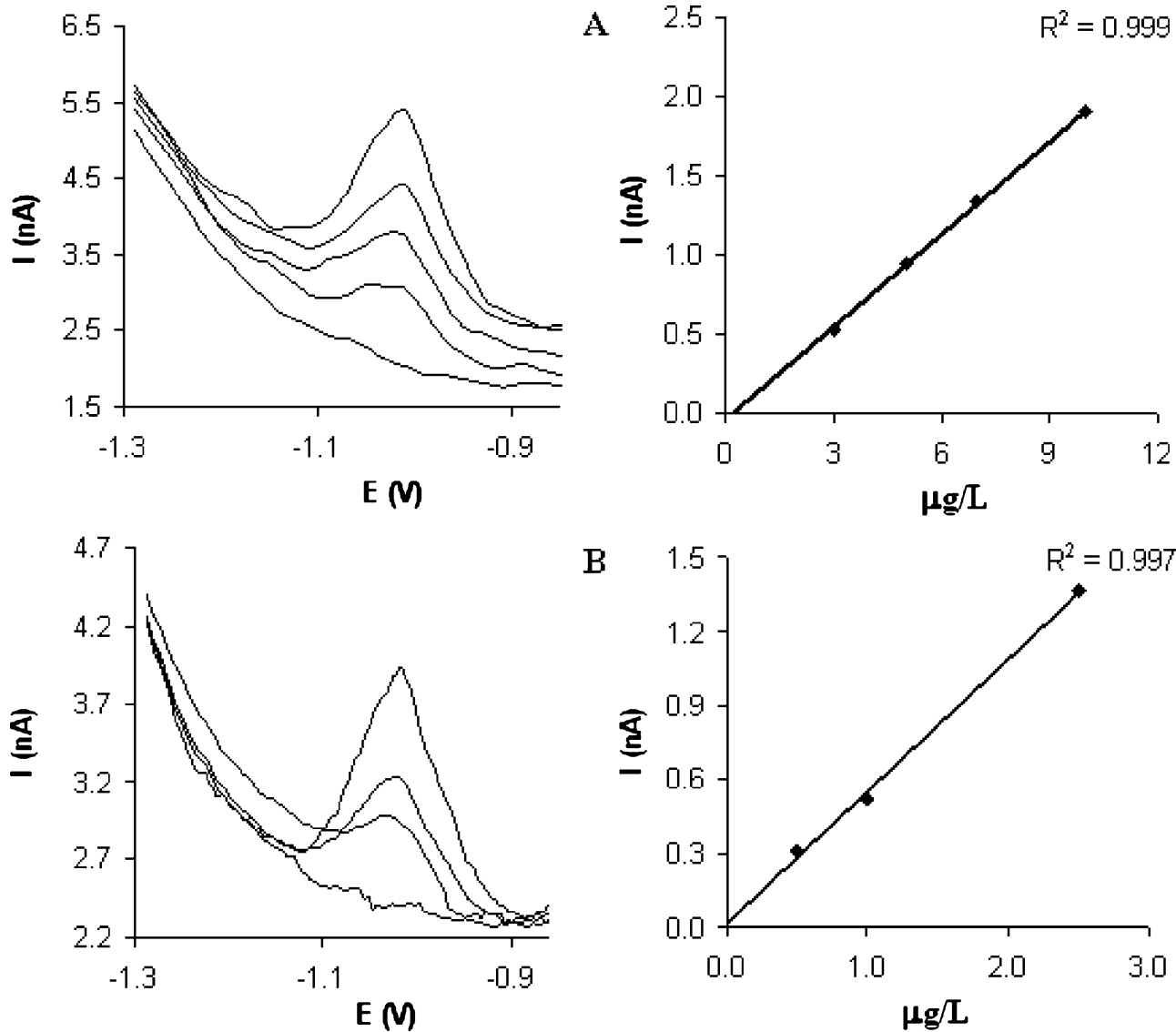
a slower passivation and therefore a more stable electrode surface.

Application of $\mathrm{Ag}-\mathrm{Cu}$ electrodes in differential pulse anodic stripping voltammetry

Differential pulse anodic stripping voltammetry (DPASV) was carried out in ultrapure water to study the sensitivity of the important trace and heavy metals zinc, cadmium and lead. As seen from Figs. 3, 4 and 5, good linearity $\left(r_{\mathrm{avg}}=\right.$ 0.998) was found for all three metals in the sub- and low- $\mu \mathrm{g} \mathrm{L}^{-1}$ range.

Only minor shifts in peak potentials for the studied metals were observed when comparing the different electrodes. As observed, the peaks for lead and cadmium were found to be relatively close. However, compared to pure sliver electrode the alloy electrodes showed a somewhat better separation of cadmium and lead, and the separation was found to slightly increase with amount of copper added. The somewhat improved separation was a result of a slight shift towards a more positive value for the cadmium peak, and a slight shift towards a more negative value for the lead peak. However, the observed shifts in peak potentials were only within a few $\mathrm{mV}(5$ to $10 \mathrm{mV})$ in each direction. A difference of about $50 \mathrm{mV}$ was observed using the silver electrode containing 17\% added copper. An second and important observation was that the sensitivity for lead was significantly better compared to cadmium on the pure silver electrode, making it difficult to detect the cadmium peak when the concentrations of the two metals were equal. On the silver-copper alloy electrodes the sensitivity to lead was decreased with the amount of added copper, and for the silver electrode containing 17\% added copper the sensitivity for lead and cadmium was approximately the same.

All peak potentials were further observed to be shifted compared to corresponding measurements using electrodes in the $\mathrm{mm}$ scale with added supporting electrolyte. The shift in peak potentials, compared to the condition using conventional electrodes and supporting electrolytes, can be explained from the fact that the measurements were carried out in ultrapure water only. However, some anions could be present in the solutions since all standard solutions were made of diluted metal nitrate solutions, but the contribution of nitrates from the standard additions is assumed to be relatively small or not significant. In addition, chloride may contribute by leakages from the reference electrode, but the presence of anions in the solutions should all in all be low. This was confirmed by separate measurements of the conductivity in samples where a reference electrode was
Fig. 4 DPASV of standard additions of cadmium a 1,3 , $5,7 \mu \mathrm{g} \mathrm{L}^{-1}$ and b $0.5,1$, $1.5 \mu \mathrm{g} \mathrm{L}^{-1}$. All measurements were performed in ultrapure water using a silver electrode containing $17 \%$ added copper, scan rate was $15 \mathrm{mV} \mathrm{s}^{-1}$, modulation pulse $70 \mathrm{mV}$ and deposition times were $600 \mathrm{~s}$ (a) and 1,200 s (b) at $-1,250 \mathrm{mV}$. Relative standard deviation was $2.4 \%(n=5)$
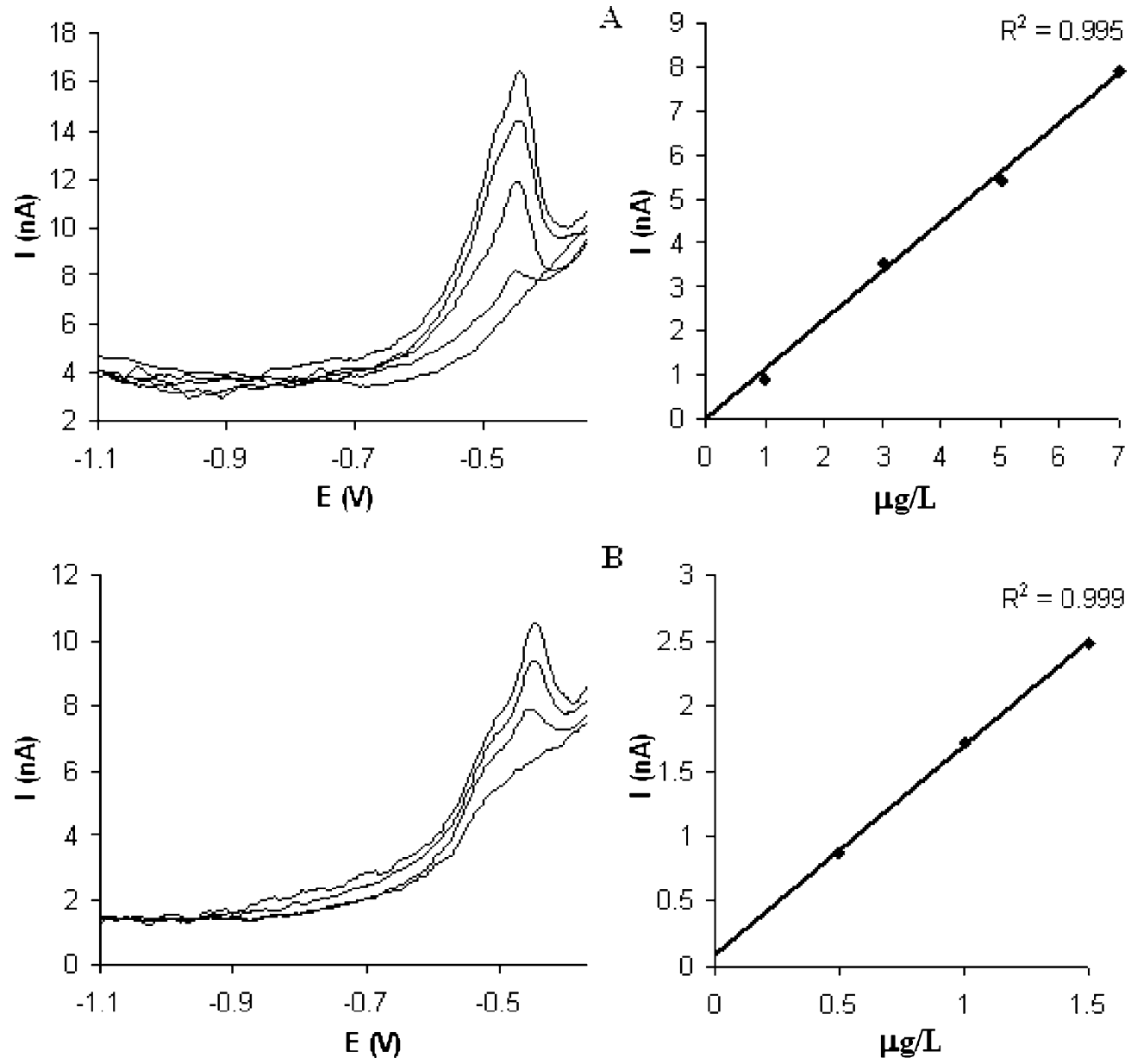
Fig. 5 DPASV of standard additions of lead a $1,2,3,5,7$, $10 \mu \mathrm{g} \mathrm{L}^{-1}$ ) and b $0.5,1,1.5,2$, $2.5 \mu \mathrm{g} \mathrm{L}^{-1}$ in ultrapure water using a silver electrode containing 17\% added copper. The scan rate was $15 \mathrm{mV} \mathrm{s}^{-1}$, modulation pulse $70 \mathrm{mV}$ and deposition time were $600 \mathrm{~s}$ (a) and 1,200 s (b) at $-1,250 \mathrm{mV}$. Relative standard deviation was $2.5 \%(n=5)$
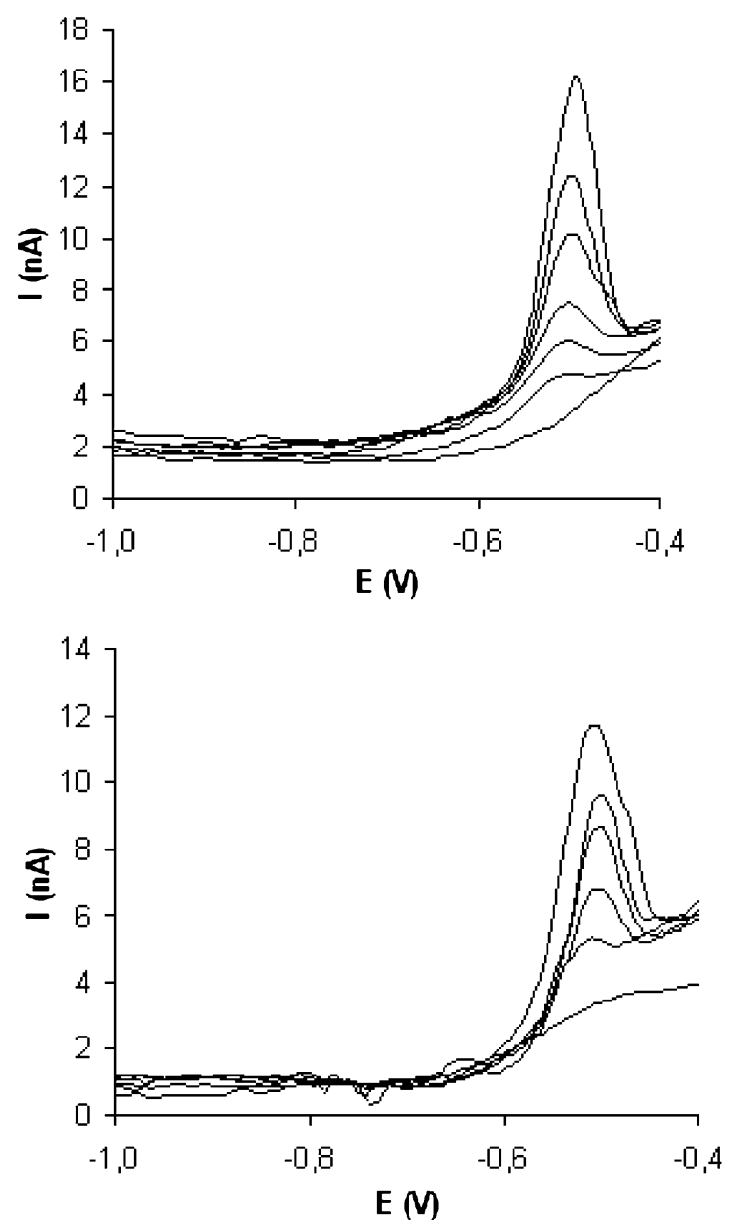

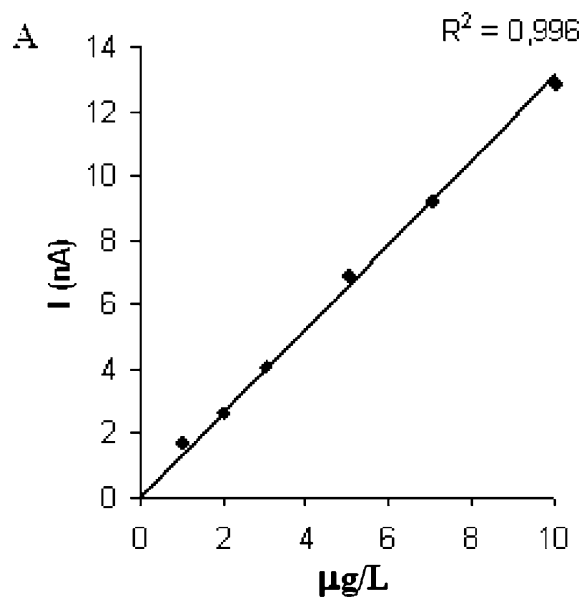

B

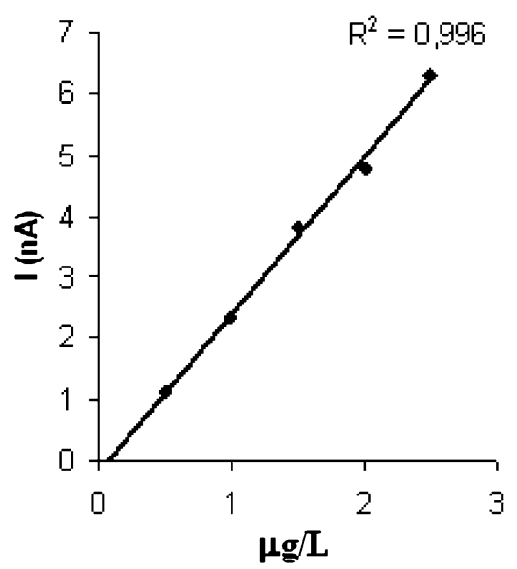

left for a period of time similar to the measuring time used in the analyses.

Normally, if anions like chloride are present in a significant amount, the potential for the cadmium peak is more negative than the peak potential for lead. The explanation for the significant shift in the peak potentials for cadmium observed here comes from the low ionic strength in the solutions, resulting in an IR drop significantly different from solutions with a higher ionic strength. Due to difference in diffusion constants the studied metals will be influenced to different extents upon the stripping process, and significant shifts in peak potentials are expected compared to solutions with higher ionic strengths [46]. It is also important to consider the nature of the different types of electrodes, which plays an important role in the process.

As observed in Figs. 3, 4 and 5 there is a change in the slope of the standard addition curves between the higher concentration series compared to the slope for the low concentration series. However, the overall relative standard deviation for these measurements was on average $2.7 \%$. Taking into account the relative standard deviation in these measurements, the interceptions are slightly outside the standard deviation for cadmium. The slightly positive
Fig. 6 Measurements of nickel with Ad-DPCSV, using a working electrode of silver containing $17 \%$ added copper. Standard addition of $0.5,1,2.5$, $5,7.5$ and $10 \mu \mathrm{g} \mathrm{L}^{-1}$ nickel, in ultrapure water containing DMG $(210 \mu \mathrm{M})$ and ammonium buffer $(\mathrm{pH}=8.6)$. The scan rate was $15 \mathrm{mV} \mathrm{s}^{-1}$, modulation pulse $70 \mathrm{mV}$ and adsorption time $120 \mathrm{~s}$ at $-450 \mathrm{mV}$. Relative standard deviation was $3.5 \%$ $(n=5)$
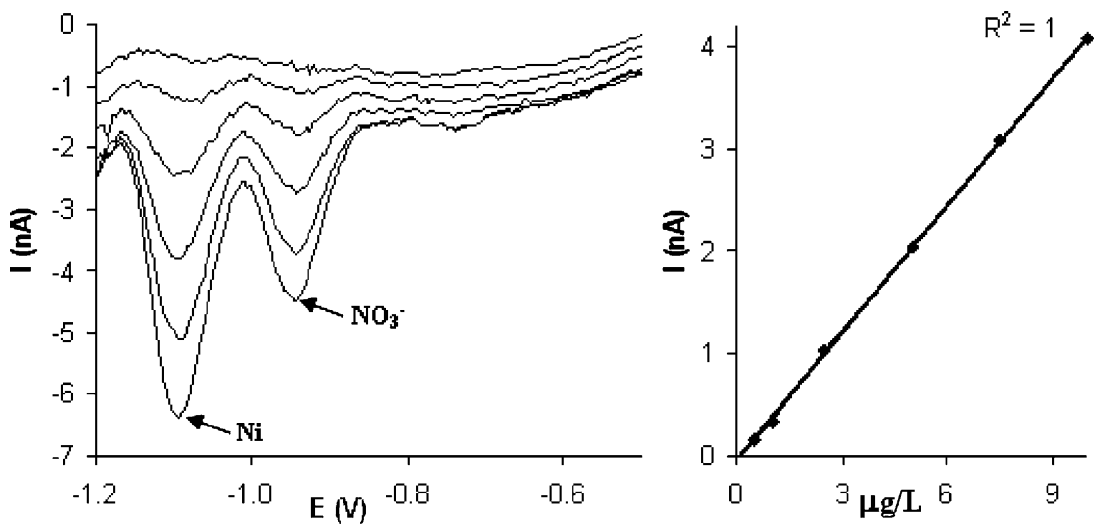
interception is difficult to explain, but could be due to small changes in $\mathrm{pH}$ over the electrode surface due to the very long deposition time, and some temperature effects could also occur. With a 20 -min deposition time, the total time at room temperature for the three standard additions will be over 60 min for each sample parallel, so this could explain some of the positive interception. Some smaller changes in the ionic strength as a result of adding the standards could also have an effect. For lead, a slightly negative interception was observed.

Application of the $\mathrm{Ag}-\mathrm{Cu}$ electrode in differential pulse cathodic stripping voltammetry

Nickel was detected by adsorptive cathodic stripping voltammetry by using dimethylglyoxime (DMG) complexation [47]. Adsorption of the nickel-DMG complex was not straightforward, as it initially was difficult to establish good linearity. However, by including a preparation step which involved applying a potential of $-1,350 \mathrm{mV}$ for $25 \mathrm{~s}$ on the working electrode just before the adsorption step, good linearity $\left(r^{2}=1\right)$ was achieved as seen in Fig. 6.

An explanation for the significant increase in linearity which was observed after including the preparative step can be found from the fact that between voltammetric measurements the electrode is rested at a potential where no current flows (open circuit potential). This potential was observed to be around $-50 \mathrm{mV}$ for the silver-copper electrode. Under these conditions adsorption of the nickelDMG complex can occur, resulting in a non-linearity in standard addition analyses. Another explanation could be that oxide layers form on the electrode under these resting conditions and alter the properties of the electrode surface. By conditioning the electrode, by applying a large negative potential before a new measurement is performed, potentially adsorbed species and oxide layers will be removed: a freshly regenerated surface will be created, giving more reproducible results.

As seen from Fig. 6 two peaks were observed in the measurements of nickel. The peak observed at $-950 \mathrm{mV}$ can be assigned to increasing presence of nitrate, as the added nickel was from a standard nickel nitrate solution. Addition of nitrate only resulted in an increase in this peak. A further study on the detection of nitrate is described below.

Application of $\mathrm{Ag}-\mathrm{Cu}$ electrodes for detection of nitrate

Several papers have been published on the subject of fundamental processes associated with the reduction of nitrate with various metal substrates [48-56]. However, only a few papers focus on the analytical aspect, and the possibility of using voltammetric techniques with solid
Fig. 7 Differential pulse voltammetry of nitrate in ultrapure water (initially $18 \mathrm{M} \Omega \mathrm{cm}$ ). Upper left part of the figure shows the voltammograms for several standard additions of nitrate ranging from $1 \mathrm{mg} \mathrm{L}^{-1}$ to $100 \mathrm{mg} \mathrm{L}^{-1}$ with linearity curve below. Upper right part shows the first 10 additions (ranging from $1 \mathrm{mg} \mathrm{L}^{-1}$ to $10 \mathrm{mg} \mathrm{L}^{-1}$ ) of nitrate with a linearity curve for the first 4 standard additions below. DPV scans from $-450 \mathrm{mV}$ to $-1,500 \mathrm{mV}$, using a scan rate of $15 \mathrm{mV} \mathrm{s}^{-1}$ and modulation pulse of $-75 \mathrm{mV}$. Measurements were performed within 1 min after addition
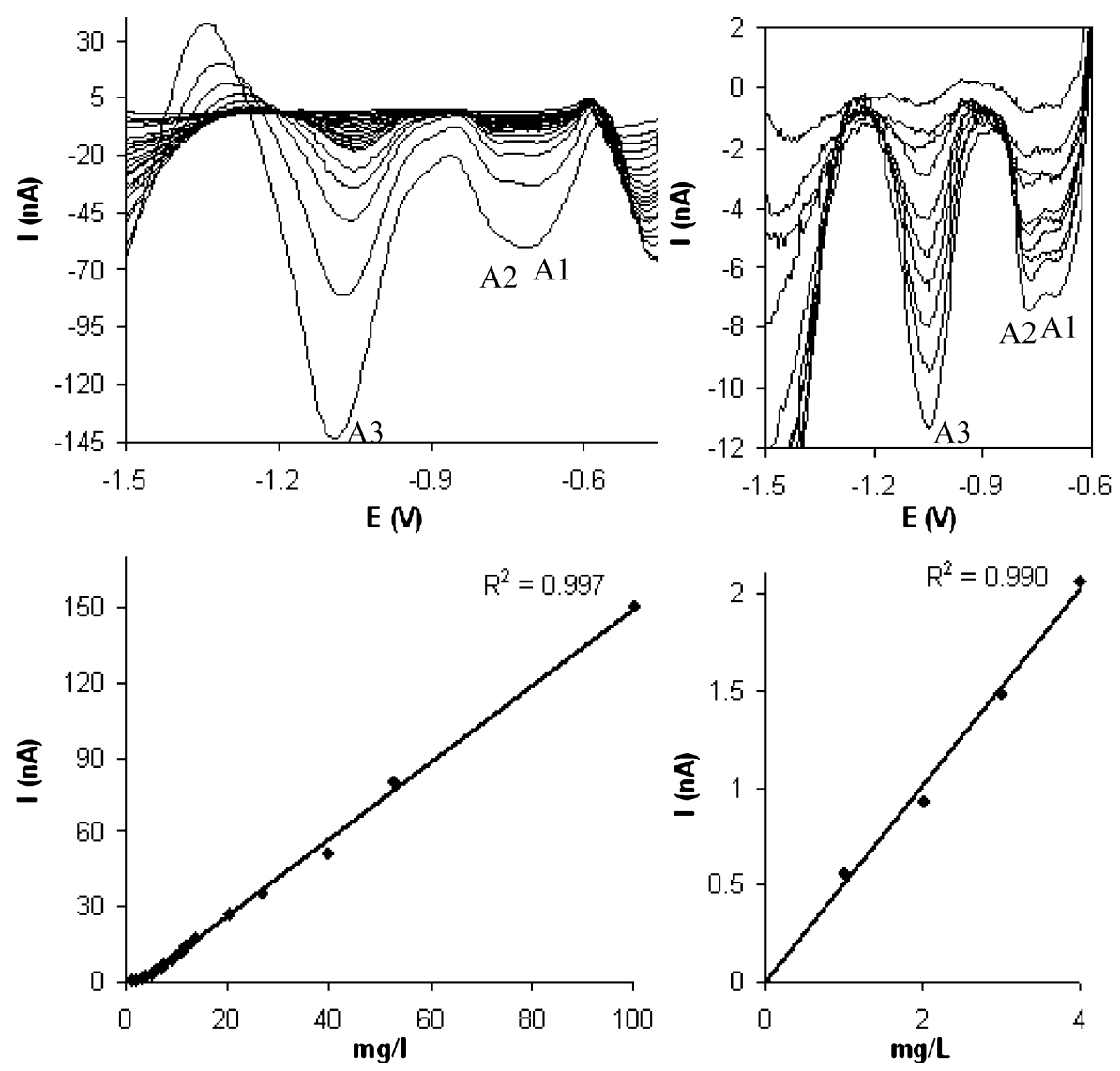
electrodes for determination of nitrate in the environment [57-63].

From the study of nickel, it was found that silver-copper alloy electrodes could be useful for detection of nitrate. A study of the ability to determine nitrate on such electrodes was therefore carried out on a silver electrode containing $17 \%$ added copper (830 silver) using differential pulse voltammetry. Pretreatment of the electrode was carried out in ultrapure water $(18 \mathrm{M} \Omega \mathrm{cm})$ as described in the "Experimental". A voltammetric scan from $-450 \mathrm{mV}$ to $-1,500 \mathrm{mV}$ was performed at a scan rate of $15 \mathrm{mV} \mathrm{s}^{-1}$. The obtained voltammograms for increasing amounts of nitrate are shown in Fig. 7. Three peaks are observed in the voltammogram: two peaks located at $-685 \mathrm{mV}$ (A1) and $-775 \mathrm{mV}$ (A2) making a plateau in this region are assumed to be connected to the electroreduction of nitrate to nitrite; a third, well-defined peak, observed at $-1,070 \mathrm{mV}$ (A3), is assumed to be connected to further electroreduction of nitrite. The observation of a double peak for nitrate could reflect a complex reduction process. However, another explanation is that this double peak could be attributed to reduction of nitrate on both silver-copper sites and pure silver sites on the electrode. Since this work is focussed on the analytical application of the silver-copper alloy electrodes, a more fundamental study of the reduction process of nitrate on these electrodes will be submitted in a later communication.

Figure 7 shows that the slopes of the two linearity curves are different. The linearity curve given in the left part of the figure reports the linearity for all standard additions in the range from $1 \mathrm{mg} \mathrm{L}^{-1}$ to $100 \mathrm{mg} \mathrm{L}^{-1}$ with a slope of 1.5 , whereas the curve in the right part reports the linearity for the first four additions only $\left(1 \mathrm{mg} \mathrm{L}^{-1}\right.$ to $\left.4 \mathrm{mg} \mathrm{L}^{-1}\right)$ having a slope of 0.5 . The difference in the slopes can be explained from the fact that addition of nitrate was started in ultrapure water only. This resulted in a significant change in the conductivity of the sample solution during the first few additions. To demonstrate this, a separate linearity curve was drawn for the first four additions of nitrate.

When comparing Figs. 6 and 7 the results indicate that the presence of nitrate may interfere with the measurements of nickel. However, measurements of nickel as dimethylglyoxime complex are carried out in an ammonium buffer solution ( $\mathrm{pH}$ 8.6). In this matrix only one peak at $-950 \mathrm{mV}$ was observed for nitrate, and a distinct separation between nitrate and added nickel was observed as shown in Fig. 8.

Zinc and cobalt may be expected to interfere in detection of nitrate in natural or acid solutions. However, the concentration of these metals must then be several $\mathrm{mg} \mathrm{L} \mathrm{L}^{-1}$ and several orders of magnitude higher than concentrations found in environmental samples like river water and lakes.

Application in real samples (polluted river water)

A voltammetric system, as described in the "Experimental", was used for detection of zinc and lead in the polluted river Deûle near the town of Douai (France). The

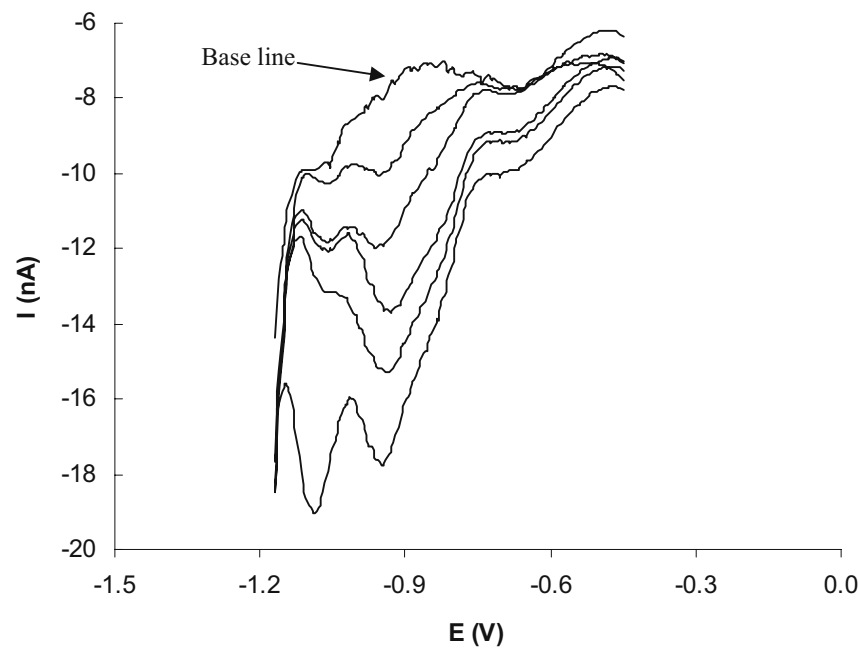

Fig. 8 Standard additions of $3.2,6.5,13$ and $26 \mathrm{mg} \mathrm{L}^{-1}$ nitrate and then $5 \mu \mathrm{g} \mathrm{L}^{-1}$ nickel in ammonium buffer solution $(\mathrm{pH} 8.6)$. Differential pulse voltammetry scanning from $-450 \mathrm{mV}$ to $-1,200 \mathrm{mV}$ with a scan rate of $15 \mathrm{mV} \mathrm{s}^{-1}$, and a modulation pulse of $-75 \mathrm{mV}$

measuring site in the river was located 500-m upstream from a former metallurgic industrial area (Metaleurop industry). Measurements were carried out over a period of $3 \mathrm{~h}$. Manual samples (filtered and unfiltered) for later analyses with ICP-MS were collected for comparison each time a new measurement was performed.

As shown in Fig. 9, significant amounts of zinc and lead were found as expected due to former and present activity in the area. In addition to zinc and lead, a third peak probably corresponding to iron is observed at $-800 \mathrm{mV}$. Furthermore, an unidentified peak at $-300 \mathrm{mV}$ is observed as well. It is beyond the scope of this paper to explain the amounts of metals found in the river water; however, there is no doubt that several processes will influence the present metal concentration in the river, including temperature, precipitation and complexation or adsorptions on particles. General activities in the area like former industrial activity, the significant traffic of cargo boats on the river, nearby highways, and the geology in the area will all be important factors in this complex system. In this contribution the discussion will be limited to presentation of results from voltammetric analyses together with parallel data from ICP-MS to verify the results and to study the difference in electro-labile and total amounts of the metals.

As seen in Fig. 9, comparable measurements with ICPMS on manually collected and filtered river samples are in good agreement with the voltammetric at-line measurements. The concentration of lead seems to increase slightly during the period, whereas the concentration of zinc seems to slightly decrease. The same trend was found in the ICPMS measurements of the river water. The $\mathrm{pH}$ was found to be $7.9 \pm 0.1$. The slight changes in zinc and lead concentrations are most likely due to interactions with organic compounds, particles and the biological activity in the river water.

As mention above, ICP-MS measurements of manually sampled river water were carried out. It is interesting to 
Fig. 9 Left comparison of voltammetric measurements with ICP-MS (filtered samples adjusted to $\mathrm{pH} 2$ with added $\mathrm{HNO}_{3}$ ) results. Right DPASV atline measurements, plating time was $300 \mathrm{~s}$, scan rate $15 \mathrm{mV} \mathrm{s}^{-1}$, and modulation pulse $50 \mathrm{mV}$. The last scan was performed in river water containing $30 \mathrm{ppb}$ added $\mathrm{Zn}$ and $30 \mathrm{ppb}$ added $\mathrm{Pb}$. Relative standard deviation for ICP-MS was within $1 \%$
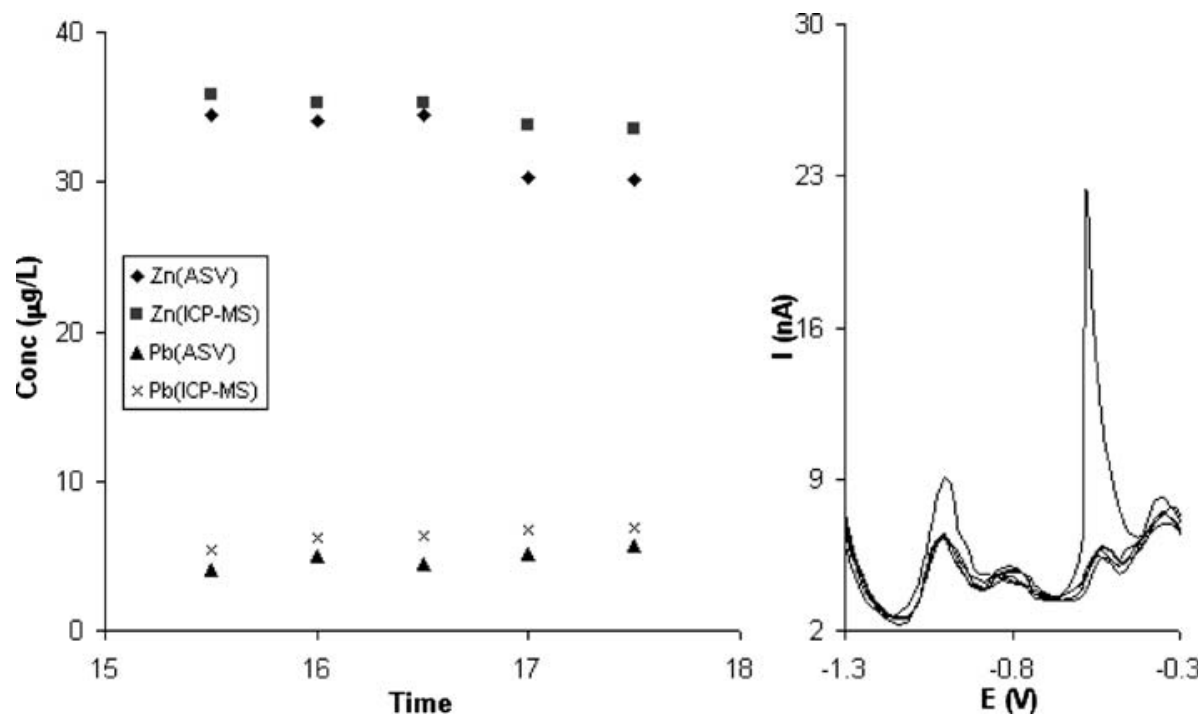

study the metal concentrations found in filtered and unfiltered samples. Results obtained from filtered samples correspond approximately to the electro-labile fraction of metals, which is supported by Fig. 9. This figure shows that concentrations obtained from ICP-MS slightly exceed the amounts found by voltammetry, and that the results follow the same trend. Concentrations found in unfiltered samples reflect the total amount of the respective metals. The differences in concentrations between the unfiltered and the filtered samples reflect the amount of metals strongly bound in complexes or in particles. The results from the unfiltered samples showed that the total amount of metals decreased through the test period. Comparison of the filtered and unfiltered samples showed that the amount of metals bound in particles was $60 \%$ for zinc and almost $80 \%$ for lead. One interesting aspect was also that the amount of metal bound in particles varied much more than the labile and complexed amount.

Oxygen was not removed since the intention was to perform the measurements in a sample as similar as possible to the original sample. Tests performed in samples purged with nitrogen did not show any significant changes.

\section{Repeatability of DPASV}

Stability over time was tested by repetitive measurement in the same sample every $0.5 \mathrm{~h}$ during a 16 -h period, using a homemade potentiostat. No decrease in sensitivity was observed during this period as seen in Fig. 10.

\section{Conclusions}

The electrochemical properties and abilities of silvercopper alloy electrodes for use in the field have been studied. Their properties have been examined according to results obtained by applying different modes of voltammetry.
Results from cyclic voltammetry and differential pulse stripping voltammetry show that silver electrodes containing added copper increase their overvoltage towards hydrogen with increasing amounts of copper in the electrode. Studies of oxide products interestingly showed that the mixed electrodes behaved as a combination of pure copper and pure silver electrodes; however, silver was found to dissolute more slowly from the alloy compared to pure silver, and the alloy electrodes were found to be more stable than pure silver electrodes.

Linearity was found for zinc, cadmium and lead in the sub- and low- $\mu \mathrm{g} \mathrm{L}^{-1}$ range in DPASV mode, and for nickel in DPCSV mode. Good linearity was also found for nitrate. The electrodes were stable for a long period of time and the results found in real samples were in good agreement with results obtained by ICP-MS. The combination of a higher overpotential towards the hydrogen evolution reaction and

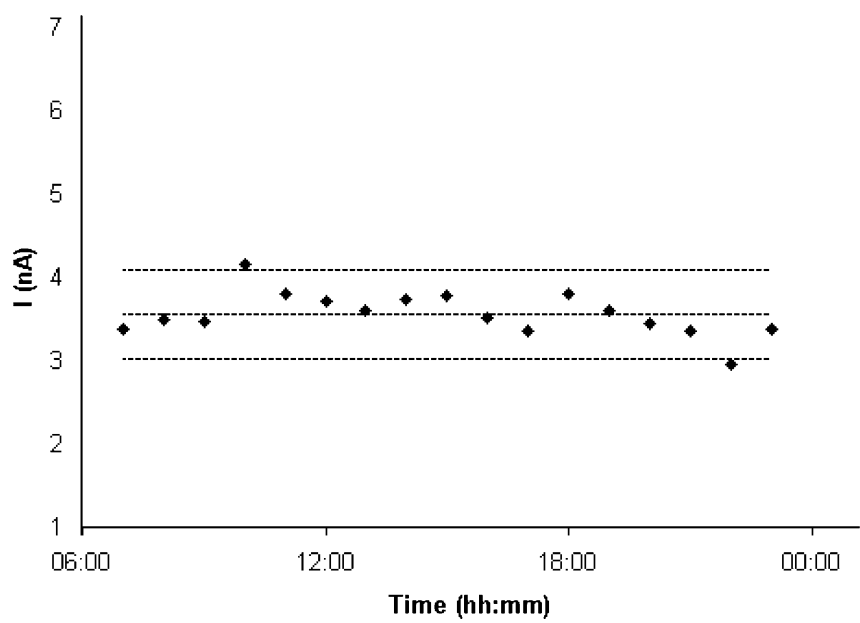

Fig. 10 Repeatability test in real sample from the river Deûle. Peak heights for zinc are plotted as a function of time. Repetitive measurements in the same sample during a period of $16 \mathrm{~h}$ using differential pulse stripping voltammetry with a deposition time of $240 \mathrm{~s}$ at $-1,250$, a scan rate of $15 \mathrm{mV} \mathrm{s}^{-1}$ and a modulation pulse of $75 \mathrm{mV}$. Upper and lower horizontal lines indicate $2 \times$ standard deviation 
a better stability greatly extends the range of analytical applications and opens possibilities for online use in the field.

\section{References}

1. http:// www.johannesburgsummit.org/html/documents/summit docs/plan_final1009.doc

2. http://europa.eu.int/comm/environment/water/water-franework/in dex en.html

3. Utgikar VP, Chaudhary N, Koeniger A, Tabak HH, Haines JR, Govind R (2004) Water Res 38:3651-3658

4. Ho JW, Ho AW (1997) Environ Toxicol Water Qual 12: 245-248

5. Madoni P, Davoli D, Gorbi G (1994) Bull Environ Contam Toxicol 53:420-425

6. Kalvoda R (1990) Electroanalysis 2:341-346

7. Mikkelsen Ø, Skogvold SM, Schrøder KH (2005) Electroanalysis $17: 431-439$

8. El-Hasani SR, Al-Dhaheri SM, El-Maazawi MS, Kamal MM (1999) Water Sci Technol 40:67-74

9. Bond AM (1999) Anal Chim Acta 400:333-379

10. Brainina Kh, Henze G, Stojko N, Malakhova N, Faller C (1999) Fresenius J Anal Chem 364:285-295

11. Diederich HJ, Meyer S, Scholz F (1994) Fresenius J Anal Chem 349:670-675

12. Tercier ML, Buffle J, Graziottin F (1998) Electroanalysis 10:355-363

13. Wang J (2005) Electroanalysis 17:1341-1346

14. Goodwin A, Lawrence AL, Banks CE, Wantz F, Omanović D, Komorsky-Lovrić S, Compton RG (2005) Anal Chim Acta 533:141-145

15. Achterberg EP, van den Berg CMG, Boussemart M, Davison W (1997) Geochim Cosmochim Acta 61:5233-5253

16. Pižeta I, Billon G, Omanović D, Cuculić V, Garnier C, Fischer JC (2005) Anal Chim Acta (paper available online)

17. Luther III GW, Wilk Z, Ryans RA, Meyerson AL (1986) Mar Pollut Bull 17:535-542

18. Mikkelsen Ø, Skogvold SM, Schrøder KH (2005) Electroanalysis 17:431-439

19. Borgo CA, Ferrari RT, Colpini LMS, Costa CMM, Baesso ML, Bento AC (1999) Anal Chim Acta 385:103-109

20. Bonfil Y, Brand M, Kirowa-Eisner E (1999) Anal Chim Acta 387:85-95

21. Cavalleri O, Bittner AM, Kind H, Kern K (1999) Z Phys Chem 208:107-136

22. Wang J, Lu JM, Hocevar SB, Farias PAM, Ogorevc B (2000) Anal Chem 72:3218-3222

23. Cordon F, Ramírez SA, Gordillo GJ (2002) J Electroanal Chem 534:131-141

24. Ensafi AA, Zarei K (2000) Talanta 52:435-440

25. Hutton EA, van Elteren JT, Ogorevc B, Smyth MR (2004) Talanta 63:849-855

26. Wang J, Lu J (2000) Electrochem Commun 2:390-393

27. Kefala G, Economou A, Voulgaropoulos A, Sofoniou M (2003) Talanta 61:603-610

28. Chi Q, Göpel W, Ruzgas T, Gorton L, Heiduschka P (1997) Electroanalysis 9:357-365

29. Brainina KZ, Kubysheva IV, Miroshnikova EG, Parshakov SI, Maksimov YG, Volkonsky AE (2001) Field Anal Chem Technol 5:260-271
30. Mikkelsen Ø, Schrøder KH (2002) Anal Lett 33:3253-3269

31. Mikkelsen Ø, Schrøder KH, Aarhaug TA (2001) Collect Czech Chem Commun 66:465-472

32. Mikkelsen Ø, Schrøder KH (2002) Anal Chim Acta 458: 249-256

33. Pižeta I, Billon G, Fischer JC, Wartel M (2003) Electroanalysis 15:1389-1396

34. Tercier M-L, Parthasarathy N, Bufle J (1995) Electroanalysis 7:55-63

35. Jiang JH, Wu BL, Cha CS, Zhai RS (1998) Electroanalysis 10:343-346

36. Matysik FM, Gläser P, Werner G (1993) Anal Bioanal Chem 349:646-649

37. Norouzi P, Ganjali MR, Sepehri A, Ghorbani M (2005) Sens Actuators B 110:239-245

38. Baldo MA, Bragato C, Mazzocchin GA, Daniele S (1998) Electrochim Acta 43:3413-3422

39. Billon G, van den Berg CMG (2004) Electroanalysis 16: 1583-1591

40. Wieckowski A (1999) Interfacial electrochemistry, theory, experiments, and applications. Marcel Dekker, Basel

41. Hayden BE, Hodgson A (1999) J Phys Condens Matter 11:8397-8415

42. Abd El Rehim SS, Hassan HH, Ibrahim MAM, Amin MA (1998) Monatsh Chem 129:1103-1117

43. Assaf FH, Zaky AM, Abd El-Rehim SS (2002) Appl Surf Sci 187:18-27

44. Zaky AM (2001) Br Corros J 36:59-64

45. Hansen M, Anderko K (1958) Constitution of binary alloys 18 . McGraw Hill, New York

46. Ciszkowska M, Stojek Z (1999) J Electroanal Chem 466: 129-143

47. Colombo C, van den Berg CMG (1997) Anal Chim Acta 337:29-40

48. Bodini ME, Sawyer D (1977) Anal Chem 49:485-489

49. Davenport RJ, Johnson DC (1973) Anal Chem 45:1979-1980

50. Genders JD, Hartsough D, Hobbs DT (1996) J Appl Electrochem 26:1-9

51. Cattarin S (1992) J Appl Electrochem 22:1077-1081

52. Fedurco M, Kedzierzawski P, Augustynski J (1999) J Electrochem 146:2569-2572

53. Fogg AG, Scullion SP, Edmonds TE, Birch BJ (1991) Analyst 116:573-579

54. Shibata M, Yoshida K, Furuya N (1998) J Electrochem Soc 145:2348-2353

55. Bouamrane F, Tadjeddine A, Butler JE, Tenne R, LevyClement C (1996) J Electroanal Chem 405:95-99

56. Tenne R, Patel K, Hashimoto K, Fujishima A (1993) J Electroanal 347:409-415

57. Pletcher D, Poorabedi Z (1979) Electrochim Acta 24: 1253-1256

58. Albery WJ, Hagged BGD, Jones Ch.P, Pritchard MJ, Svanberg LR (1985) J Electroanal Chem 188:257-263

59. Fogg AG, Scullion P, Edmonds TE (1991) Analyst 116: 573-579

60. Davenport RJ, Johnson DC (1974) Anal Chem 46:1971-1978

61. Kvarackheliya PK, Machavariani T.Sh (1982) Coll Czechoslovak Chem Commun 47:2615-2619

62. Krista J, Kopanica M, Novotný L (2000) Electroanalysis 12:199-204

63. Davis J, Moorcroft MJ, Wilkins SJ, Compton RG, Cardosi MF (2000) Analyst 125:737-741 